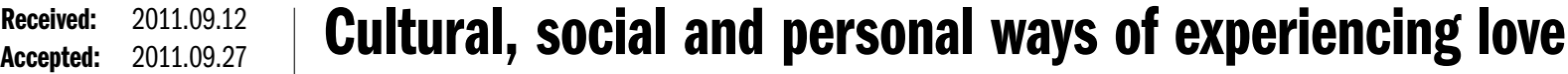 \\ Published: 2011.11.01 \\ - an analysis of the perception of subjectivity
}

\section{Claudia Gori}

European University Institute, Florence, Italy

Source of support: Self financing

\section{Summary}

This article is based on analysis of 4 couple's personal and public documents, in order to integrate personal choices, values and ideas with cultural representations and social attitudes. Moreover, being based on Italian sources from the nineteenth century, the study offers an historical insight on the Italian nation-building process and its political and social foundations.

This study is based on archival and printed primary sources from: Gianna Maffei and Ercole Trotti Mosti (Museo Centrale del Risorgimento - Roma - MCRR); Augusto Pierantoni and Grazia Mancini (Museo Centrale del Risorgimento - Roma); Luigi Majno and Ersilia Bronzini (Archivio Unione Femminile Nazionale - Milano); Angiolo Orvieto and Laura Cantoni (Archivio Contemporaneo Bonsanti del Gabinetto Vieuesseux - Firenze - ACGV).

This study reflects on love as a political and moral issue, by linking the personal sphere of subjectivity to the public dimension of the political community. An extensive understanding of the role played by the perception and the expression of sentiments can be considered as the central issue of this analysis.

key words: $\quad$ love $\bullet$ sentiments $\bullet$ emotions $\bullet$ subjectivity $\bullet$ politics $\bullet$ culture $\bullet$ society $\bullet$ gender

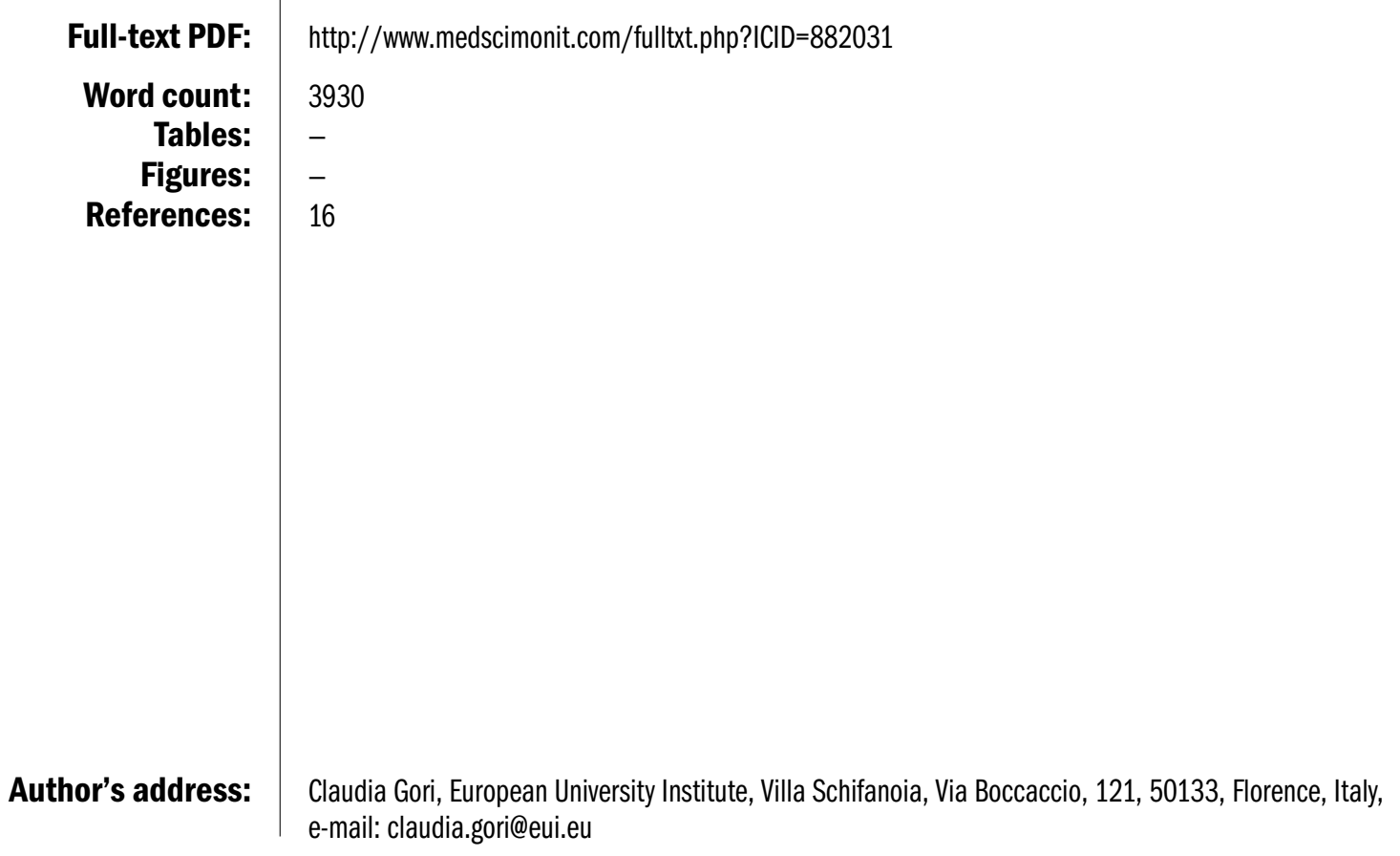




\section{Methodological Perspective}

This research is based on romantic correspondences between 4 couples in Italy during the nineteenth century. Each correspondence is sourced from an ample selection of personal, private and public sources, such as diaries, agendas, personal notes, family letters, public discourses, juridical pamphlets and literary writings [1]. The variety of personal and public documents allowed me to consider the personal space of subjectivity and the public sphere of the political community.

First, I examined the dimension of subjectivity by considering the ways in which sentiments had been formed and expressed. I took into account the cultural space in which emotions had been elaborated, the question of personal choices in the definition of moral actions and values, and the personal interpretation of sentiments (which implies a specific way of feeling and a certain interpretation of moral values) [2]. I considered personal reactions to family values and the space of personal creativity and beliefs. I moved between cultural codes (the space of imagery and cultural beliefs) and personal ways of thinking and acting [3]. Specifically, I considered the linguistic codes and the different ways of expressing emotions. I assumed, in fact, a deep relationship between the space of subjectivity and the level of language, considering that language is one of the most intimate ways of relating to each other as human beings. I analyzed the letters as cultural and linguistic documents, trying to identify in them emotions and sentiments, and to study their modes of expression. I also considered the issue of rationality not as an objective and universalistic theme, but as a matter profoundly related to the identification and elaboration of personal sentiments and emotions.

As a second step, and as concerns the level of the political community, I specifically moved between cultural representations and social conditions. I paid specific attention to the personal dimension, analyzing the literary, political and juridical pamphlets of the personalities studied [4]. Both men and women, in fact, found a way to participate in the public sphere, even if gender roles were different and defined by diverse political and social positions [5]. By referring to the concept of the political community, I used a broad definition of the public domain of politics. It is therefore implicit that, in the history of the nineteenth century, I concentrate my attention on the nation-building process, taking into account the definition of the State and the imagery of the nation [6]. In particular, the history of Italy was marked by forty years of struggles for its unity (the Risorgimento process, 1821-1861) and then by the construction of a liberal State (1861-1922), in which the bourgeoisie had a hegemonic position [7]. The bourgeois of the liberal State defined the practice of citizenship in terms of exclusion of gender and class. The debate concerning the exclusion from the political arena of women and the lower classes was discussed by different voices of united Italy and implied different positions inside the bourgeoisie itself. The expression of diverse public sentiments and emotions was connected to different political perspectives, with regard to national representations, social perspectives, and cultural imagery.

Thus, the four couples of my research shared similar social backgrounds in the upper and middle classes and this fact allowed me to make a comparison between them in the perspective of the national debate. More precisely, however, they expressed different perspectives on society and politics in relation to their culture and political ideas. During the nineteenth century, the Italian public sphere appeared as a complex ground for political and social issues [8].

\section{Four CASE Studies ON tHe EXPRESSION OF LOVE}

\section{Gianna Maffei and Ercole Trotti Mosti}

Gianna Maffei (1798-1879) and Ercole Trotti Mosti (1786-1828) lived during the period of the Restoration. Both their families were of noble extraction, coming from Verona and Ferrara, respectively. Their love letters - which mainly covered the period of their engagement (1817-1818) - represent an extraordinary source for exploring both the political and private changes related to the passage between the ancien régime and the contemporary period. The ideal representation of the two fiancées' future marriage and future lives in their correspondence described and identified a private sphere, in which significant changes in attitude towards the modernity were expressed. Considering the age of the two spouses, their social condition, and their high degree of social compatibility, the marriage between Gianna and Ercole was coherent with the aristocratic strategies of alliance between families, which was the traditional custom of the ancien régime. The traditional rules for marriage were thus maintained, but the reciprocal compatibility between the fiancées was based on the representation of love and the Romantic idealization of sentiments.

Through a sophisticated use of language, Gianna and Ercole described their reciprocal desire, their emotions and their feelings, giving an abstract representation of their love. The expression of sentiments became the main argument of the intimate dialogue between the two fiancées and was based on a subtle search for appropriate words to declare their reciprocal love. Nonetheless, they also discussed and agreed on the values and objectives of their projected life in common, with its real and concrete dimension. Specifically, the two fiancées elaborated and interpreted Rousseau's model of the family, which focused on the world of feelings, rejecting the excesses of the beau monde and valuing a parsimonious life based on harmony between the "world outside" and the "world inside". In contrast with Rousseau [9], however, there were important differences in the definition of the role of the woman, and concerning some social and political aspects of their union. The idea that husbands should form the character of the wife was explicitly reaffirmed, as was the notion that it was up to him to govern the family. What kind of behavior was correct for a noble woman became an issue of discussion between the two fiancées, particularly when Gianna behaved too independently, speaking freely of literature. The hierarchy between men and women was treated as a fact, although - in the case of this couple the importance of love also became an important element of increasing equality. Ercole used the idea of love to reinterpret his role as a nobleman. As a consequence, gentility, transparency and faithfulness became, for him, important elements of self-identification and self-perception. His relationship with Gianna was marked by the importance of reciprocal faith and transparency, and by the need to be reciprocally confident "in mind and soul". 
Oh si si, mio ben amato solo amato Mosti, sì lo credo lo vedo che tu mi ami, che tu m'ami come io desidero tu il faccia, come certamente (oh credilo pure) nessun altro m'avrebbe amata giammai, ché per amare così vi vuol il tuo cuore, e ben pochi cuori per non dir nessuno rassomigliano al tuo. A quel tuo cuore che sente tanto, con tanta delicatezza, che non ama che ciò che tu stimi esser stimabile che ama la virtù, che sa così bene spandersi in quello della tua Gianna, quel tuo cuore ch'è la mia felicità, la mia sola gioia, la mia gloria.

Oh yes yes, my well-loved just loved Mosti, yes I think, I see that you love me, that you love me like I wish you to, as surely (oh, believe me as well) no one else would have loved me ever, because only your heart is capable to loving so, and few hearts, or no one, have resemblance with yours. Then your heart that feels so, so gently, that only likes what you deem to be reputable, who loves virtue, who knows so well to believe in that of your Gianna, that your heart which is my happiness, my only joy, my glory [10].

While the marriage was based on an increasing awareness of the passion between the couple, on Ercole's side the idea of love also became an instrument for interpretation of his political power. Even if, in the noble society, the distinction between the private and the public spheres was still uncertain, the letters also describe the public dimension of the lord, the head of the political community. The capacity to be loved and valued by his fiancé made Ercole aware of the importance of sagely using his political power. His love for Gianna was directly linked to Ercole's personality and selfesteem. In the letters of the engagement, in fact, the poetic language and images completely replace the tragic tones of Rousseau, and Gianna, while affirming her willingness to be guided by her future husband, was also able to find important spaces of liberty and autonomy through the declaration of her love for Ercole.

\section{Augusto Pierantoni and Grazia Mancini}

With regard to the second couple, Grazia Mancini (1842-1913) and Augusto Pierantoni (1840-1911), the language of self-expression in their letters was less intense, but maintains frequent references to literature. The choice of single words brought the language of the couple closer to that of daily life, while the political and social context is that of post-Unitarian Italy. The Pierantoni couple recognized themselves in the values of a burgeoning bourgeoisie. Augusto was a lawyer and a professor of law, while Grazia identified herself as a wife and a mother. The bourgeois way of life was mostly expressed by the separation between the private and public spheres, through the domestic duties of women and by a focus on work and professional careers for the acquisition of social prestige.

Grazia was the daughter of Pasquale Stanislao Mancini, a Neapolitan leader of the Risorgimento, a lawyer and professor of law, who after the Unity was appointed Minister of the State more than once [11]. The strong figure of her father and his renown as a scholar and a politician, an important point of reference for Neapolitan liberals before 1848 and later for the whole peninsula, strongly influenced Grazia, both before and after her marriage with Augusto. When she was younger, Grazia behaved as a perfect daughter, replacing her mother in performing the domestic duties of the household. She met Augusto, a pupil of her father's, through her family. For Augusto and Grazia, professional interests were thus interconnected with family links, and after their marriage (1868) - the two spouses continued to depend on her father's authority and his benevolence. As a consequence of this family situation, the domestic dimension of life became increasingly important for the development of Grazia's personality. She remained a daughter, as well as becoming a mother and wife. While the letters of Augusto were less numerous and were mostly related to daily life, Grazia's letters still reflected late Romantic culture, which continued to influence language. In letters written between 1866 and 1909, Grazia continued to ask for love from her husband, while the world changed around them. The presence of love was accompanied by different phases in which melancholy and solitude prevailed: these two characteristics summed up many features of Grazia's bourgeois life, which was rarely compensated by the social life of the beau monde.

Considering this private situation, however, Grazia became also a writer, and she continued this activity from her youth throughout life. During her life, literature remained for her the necessary link between the private dimension of the family and the public arena of politics, in which she participated indirectly. In her literary works, the relation between the family and the nation became important in defining the condition of women, their roles and their duties. Grazia spoke to the women of the new Italian nation and described their lives, appealing to her own family values. She insisted on the values of the Risorgimento as being female purity, loyalty and transparency, which identified a specific model for Italian women. On his side, Augusto, in his juridical pamphlets, described a nation based on the bourgeois model of the citizen, through the exclusion of women and the poor, and identified in the concept of honor the sexual metaphor of the new nation. The definition of the new nation seemed to be the most important issue in the political discourse of Grazia and Augusto, just as the ideas and the fact of the Risorgimento represented an important element of their private life. The private and the public spheres thus became separated but interconnected, related to each other through the different but complementary positions of men and women.

\section{Luigi Majno and Ersilia Bronzini}

In the last decades of the nineteenth century, the political culture of Unitarian Italy was not as homogeneous as the nationalistic discourse tried to represent. Many other voices, by discussing the same political and social issues from a different perspective, underlined various problems and represented a wide array of social subjects. In particular, the socialist discourse directly addressed the structure of the State, and its barriers of inclusion and exclusion. The significance attributed to the nation was different and the main questions that were raised directly addressed the social condition of women and lower classes.

Ersilia Bronzini (1859-1933) and Luigi Majno (1852-1915), two socialist from Milan, were also part of the bourgeoisie, given their status and, partially, their culture. Luigi was a lawyer and scholar of penal law, while Ersilia was a wife and 
mother. Socialism became part of their life during the early stage of their marriage and, fortunately, letters stretching over their life together (1877-1913), as well as other documents, have been preserved. During these early years, Luigi approached the reformist wing of the socialist party and became a friend of Filippo Turati and Enrico Ferri. He was also a member of the scuola positiva di diritto penale (Positivistic School of Penal Law), and was engaged in politics as a member of the Camera del Lavoro (Chambers of Labour) and of the City Council of Milan. Initially, Ersilia remained devoted to her family duties, but she progressively acquired a political awareness which led her to reflect on her own situation. The letters described the phases of her intimate transformation, which concerned her political awareness and her personal dimension, until she began to approach feminism and chose to become politically engaged. In the late nineteenth century, Ersilia became an important member of the women's political movement, and in 1899 she founded the Unione Femminile (Women's Union) in Milan with several other women. Bourgeois values acquired importance in this stage, through their analysis, comparison and the rejection. Starting from her personal and private sphere, Ersilia reflected upon her behavior, her ideas, and her priorities. As she moved outwards to observe society, her feelings were profoundly transformed and her reflections began to be particularly directed towards the issues of responsibility and justice. Understanding the idea of justice as applied to human relationships, pushed her to re-evaluate the traditional values of the bourgeoisie and its inherent social hierarchies.

As in the model of the nineteenth-century bourgeoisie, the family dimension represented for both Ersilia and Luigi a space for intimacy, like a retreat from the cruelty of public life. In their case, however, this specific space was also transformed and redefined through their new socialist values; the intimate space of the family became a place which testified to a new set of personal, social and gendered relationships. Moreover, through the idea of sentiments, an important link was established between the private sphere of the family and the public sphere of society. The appeal to justice, civil and social rights was based on an important affirmation of sentiments towards the political community and the moral conception of humanity. For both Ersilia and Luigi, political engagement was based on an intimate perception of social rights as social and human values:

Mio caro Majno, tu mi comprendi tanto bene ch'è per me una gran consolazione, la migliore delle ricompense, la più desiderata, è che tu approvi e trovi giusto il mio modo d'agire, è che i nostri cuori sentano all'istesso modo, che la nostra vita abbia uno scopo comune pel quale lavoreremo, non curandoci né di critiche né di lodi.

My dear Majno, you understand me so well that the great consolation for me, the best of rewards, the most desired, is that you approve and consider my way of acting to be fair, is that our hearts feel in the same way, that our life has a common purpose for which we work, without considering criticism or praise [12].

Like Ersilia, Luigi idealized the domestic space, sharing with his wife their common vision of life. In fact, when in 1900 he became Deputy at the National Parliament, he devoted much of his energy to defending Ersilia's projects promoting legislation for female workers and for the National Maternity Foundation [13]. In the case of Ersilia and Luigi Majno, the language became coherent with their positivistic criteria of action and their interest for the popular world also led to the adoption - by quotation and description - of its images. Literature in this case became important as an instrument of knowledge and to look deeply into the reality of life.

These critics of the bourgeois definition of the liberal state (which emerged, in this case, from the bourgeoisie itself) had implications for the debate in the early twentieth century. Moving again from the left wing of the intellectual Italian milieu to the more conservative wing, it is possible to observe that the debate was complex and was complicated by the contemporary political situation.

\section{Angiolo Orvieto and Laura Cantoni}

Angiolo Orvieto and Laura Cantoni were a man and woman of letters. Both Jews, they were also cousins, and they came from two related families of the rich Jewish bourgeoisie. The encounter between the two cousins was based on liberal and romantic culture, in which both of them were immersed during their youth. Angiolo had studied at the Liceo Dante of Florence and had later graduated in philosophy at the Cesare Alfieri in Florence. After a period in Germany, he founded the literary journal La Vita Nuova with some friends and became a poet. In the same period, he fell in love with a French girl, Ambroisine Izarn, who was both Catholic and poor. Since his romantic love was opposed by his family, he travelled in Europe and later in the United States, India and Japan. During these years, Angiolo's Jewish identity was softened by his love for the Italian literary tradition of which he considered himself to be a follower. His family's objection to his marriage generated in him a period of rebellion against Jewish traditions, which he believed excluded Jews from the life of their country.

Laura, who grew up in Milan, received her education at home, revealing a strong desire to study early on. Like Angiolo, she also particularly loved literature - especially Italian and English - over other subjects, becoming an intimate friend of her Scottish teacher of English. Forced to live inside the confines of her family, Laura refused however to be dominated by domestic rules and she defined herself as a rebel [14]. The first encounter with Angiolo happened during a family dinner, when Laura found the courage to speak of Giovanni Pascoli, a young poet friend of Angiolo. The two cousins liked each other and, when Angiolo came back from his travel in Asia, they met again and declared their reciprocal love, as evidenced in their letters from 1899-1940. This time, the family accepted the marriage, and Angiolo did not have to renounce his desire to choose his wife freely.

The fact that Angiolo and Laura were free to marry each other, and were not obliged to marry partners that their respective families had chosen, represented a very important moment for them and, thereby, defined their reciprocal love through literature and romanticism. Many years later, in 1939, after the passing in Italy of racial laws against the Jews, Laura, living the tragedy of persecution, significantly 
titled her autobiography Storia vera di Angiolo e Laura (True Story of Angiolo and Laura), with the aim of giving witness to their love and their lifelong marriage. During the first decades of the twentieth century, Laura came in contact with the moderate sector of the women's political movement and shared with some other female intellectuals the democratic sympathies of those years. Collaborating with Il Marzocco - the second journal founded by Angiolo and his brother Adolfo in 1896 - Laura Orvieto wrote about the condition of women, dedicating her attention especially to the issue of women's liberty and freedom [15].

In her personal dimension, she tried to open up her roles of mother and wife to the public sphere, writing professionally about literature for children. The advent of fascism devastated the fervid intellectual milieu of the early twentieth century. After the First World War, class identification pushed Angiolo to take the side of the regime. In addition, in 1936, he supported the colonial politics of the regime, just as he had in the liberal period. The beginning of the persecutions against the Jews was, however, just about to begin, and the concept of race was also used against them. Despite his persisting fidelity to the regime, Angiolo tried to avoid the worst, collaborating with other Jews for the alliance of Italy with Great Britain, instead of Germany. The Orvieto couple survived the persecutions in the late 1930s, but their experience could be seen as profoundly marked by their ambiguous position in respect of the fascist regime and the history of Italy.

\section{CONCLUSIONS}

In the four cases, and in the range of these personal experiences, the definition of love within the couple described some significant spaces for intimacy. The importance given to solidarity and care between the spouses defined the new model of the family, based on the expression of sentiments. In this reality, the four women found various possibilities to access wider spaces of freedom and personal autonomy. The expression of personal needs, love and desire helped them to recognize their subjectivity, outside the model of patriarchal relationships, between men and women. At the same time, they acquired, in their families, more possibilities to be educated. While their personal dimensions changed, the roles of the four women progressively broke the borders of the private sphere and found some possibilities to access intellectual and political debates.

The dimension of masculinity was - in the four cases - connected to the definition of the public sphere and to the model of bourgeois citizen. However, the expression of love within the couple revealed new personal and moral attitudes, which were translated into new ways of behaving. Moreover, the four men's political beliefs opened up varying - albeit significant - questions about society and social relationships. The bourgeois space for intimacy was ideally and socially connected to the definition of social and political places. In particular, the emotional link between the personal spaces and the public sphere was used to elaborate a new place for sentiments in society.
If the experience of romantic love and its social meaning was deeply related to the transformations of Italian society, its borders of inclusion and its social struggles, the political perspectives of the four couples underline some important differences in ways of interpreting national borders and political values. Significantly, the conception of love inside the couple can be linked, in the four cases, to the expression of political and social sentiments. While the personal sphere of each intellectual can be seen as emotionally related to their interpretation of society, social hierarchies and social values, it is also possible to develop from this perspective an argument on ethical issues and moral beliefs. The intimate perception of love and its modes of social and cultural expression open up new questions on themes such as human relationships, human priorities and human actions. These concerns can offer interesting elements of comparison with neuroscientists' research on these critical human emotions [16].

\section{REFERENCES:}

1. Chartier R et al: La correspondance: le usage de la lettre au XIXe siècle. Paris, Fayard 1991; Chartier R., Boureau A., Dauphin C: Correspondence: models of letter-writing from the middle ages to the nineteenth century. Cambridge, UK, Polity Press, 1997

2. Nussbaum M: Upheavals of Thought. The Intelligence of Emotions. Cambridge University Press, Cambridge, 2001

3. Passerini L: Memoria e utopia. Il primato dell'intersoggettività. Torino, Bollati \& Boringhieri 2003; Passerini L, Storie d'amore e d'Europa. Napoli, L'Ancora 2008

4. Hall C: White, Male and Middle Class. Explorations in Feminism and History. Cambridge, Polity Press 1992; Hall C, McClelland K, Rendall J: Defining the Victorian Nation: Class, Race, Gender and the British Reform Act of 1867. Cambridge, Cambridge University Press 2000 Davidoff L., Hall C.: Family Fortunes: Men and Women of the English Middle Class, 1780-1850. London, Hutchinson, 1987

5. Pateman C.: The Sexual Contract. Cambridge, Polity Press 1988; Scott J.W.: Gender and the Politics of History. New York, Columbia University Press 1988; Scott J.W. et al: Feminism and History. Oxford-New York, Oxford University Press, 1996

6. Banti AM: La nazione del Risorgimento. Parentela, santità e onore alle origini dell'Italia unita. Torino,Einaudi 2000; Banti AM, Bizzocchi R et al: Immagini della nazione nell'Italia del Risorgimento. Roma, Carocci, 2002

7. Banti AM: Storia della borghesia italiana. L'età liberale. Roma, Donzelli 1996; Banti A.M. Ginsborg P et al, Il Risorgimento, in Storia d'Italia. Annali, 22. Torino, Einaudi, 2007

8. Habermas J: Strukturwandel der Ôffentlichkeit. Untersuchungen zu einer Kategorie der Bürgelichen Gesellschaft. Suhrkamp Verlag, Frankfurt am Main 1962

9. Rousseau JJ: Julie, ou la nouvelle Hèloise. Lettres de deux amans habitans d'une petite ville au pied des Alpes recueilles et publiées par J.J. Rousseau. Londres, 1774

10. Maffei G: Lettera a Ercole Trotti Mosti, Verona, 13 aprile 1818. Roma. Museo Centrale del Risorgimento (MCRR), 577: 3

11. Pasquale Stanislao Mancini (1817-1888), after the Unity, was Minister of Education in 1862, Minister of Justice (1876-78), and Minister of Foreign Affairs (1881-1885)

12. Bronzini E: Lettera a Luigi Majno, S. Damiano, 3 agosto 1895. Milano. Archivio Unione Femminile Nazionale. Fondo Ersilia Majno Bronzini (FEMB), c. II

13. Buttafuoco A: Questioni di cittadinanza. Donne e diritti sociali nell'Italia liberale. Arezzo, Protagon 1997

14. Orvieto L: Storia vera di Angiolo e Laura. Firenze, Olschki 2001

15. Gori C: Crisalidi. Emancipazioniste liberali in età giolittiana. Milano, Angeli 2003

16. Esch T, Stefano GB: The neurobiological link between compassion and love. Med Sci Monit, 2011; 17(3): RA65-75 